\title{
Late Holocene guanaco hunting grounds in southern Patagonia: blinds, tactics and differential landscape use
}

\author{
Juan Bautista Belardi ${ }^{1, *}$, Flavia Carballo Marina ${ }^{2}$, Patricia Madrid ${ }^{3}$, \\ Gustavo Barrientos ${ }^{4} \&$ Patricia Campan $^{5}$
}

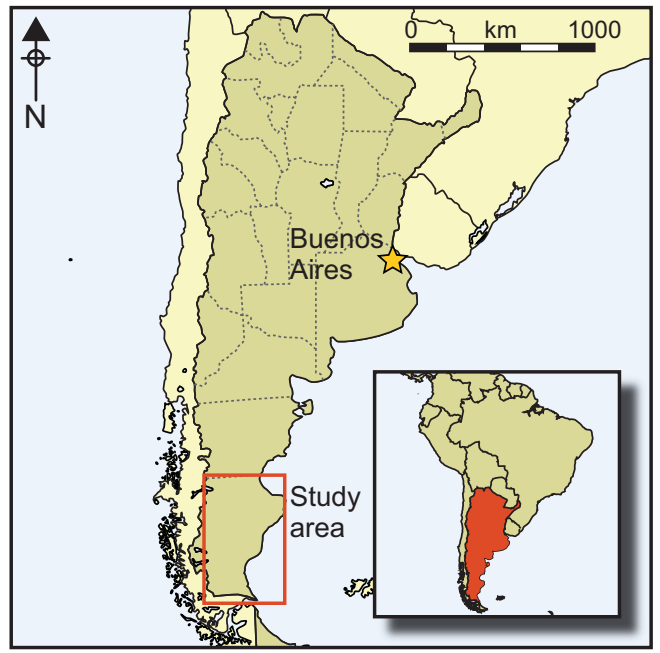

Research in two distinct steppe landscapes in southern Patagonia - the western basaltic plateaux and the central Deseado Massifcompares hunter-gatherer strategies in the two environments, focusing on the use of bunting blinds and associated tactics in the bunting of guanaco. The evidence obtained brings this region into discussions about the use of rocky structures and the recognition of tactics used for hunting ungulates in a global perspective. The authors also emphasise the importance of highland settings as major and reliable sources of critical resources for foraging peoples, a topic still not fully appreciated in archaeological studies of hunter-gatherers.

Keywords: Argentina, Patagonia, Late Holocene, guanaco, hunting strategy, hunting blinds

1 Universidad Nacional de la Patagonia Austral, Unidad Académica Río Gallegos (ICASUR), CONICET, Lisandro de la Torre 860, Rio Gallegos, Argentina

2 Universidad Nacional de la Patagonia Austral, Unidad Académica Río Gallegos (ICASUR), Lisandro de la Torre 860, Rio Gallegos, Argentina

3 Universidad Nacional de La Plata and Universidad Nacional del Centro de la Provincia de Buenos Aires (INCUAPA), Avenida Del Valle 5737, Olavarría, Argentina

4 División Antropología, Facultad de Ciencias Naturales y Museo, Universidad Nacional de La Plata, CONICET, Avenida 122 y 60, La Plata, Buenos Aires, Argentina

5 Museo Regional Provincial Padre M.J. Molina, Universidad Nacional de la Patagonia Austral, Unidad Académica Río Gallegos (ICASUR), Ramón y Cajal 51, 9400 Rio Gallegos, Argentina

* Author for correspondence (Email: juanbautistabelardi@gmail.com) 


\section{Introduction}

Hunting strategies and tactics deployed by past hunter-gatherer societies are key to understanding the changing relationships between human populations and their environment over time. This becomes especially relevant at middle and high latitudes where hunting is a crucial aspect of human subsistence (Binford 2001). The hunter-environment relationship and the degree and type of relationships within and between human groups are both equally important (Binford 1978a; Aschero \& Martínez 2001; Frison 2004; Moreno 2012; Bar-Oz \& Nadel 2013; Borrero 2013).

Hunting structures, their relationship with landscape features, and the knowledge about their spatial location and functioning (i.e. hunting strategies and tactics) can be understood not only as a part of a hunting strategy based on the construction of specialpurpose facilities or site furniture (Binford 1978b), but also as components of a built niche (Laland \& O'Brien 2010). In this context, the continuous use and transformation of the landscape-particularly of its durable components such as hunting blinds-by hunter-gatherer populations implies the notion of inherited landscapes. In fact, structural modifications to the landscape are transmitted from generation to generation as a form of ecological inheritance, whereas the knowledge necessary for successful hunting, either individual or communal, is acquired through social learning (Smith 2013).

The presence of hunting blinds (locally known as parapetos) in the western basaltic plateaux of southern Patagonia $(700-1100 \mathrm{~m}$ asl, Santa Cruz Province, Argentina) (Figure 1) was first described in the late 1950s (Gradin 1959-1960). They are mostly semielliptical stone structures built for the hunting of guanaco (Lama guanicoe). This mediumsized wild camelid was the main staple for pedestrian hunter-gatherer populations from the very outset of human settlement in Patagonia during the Late Pleistocene (Miotti 1998; Mengoni Goñalons 1999; Borrero 2001). The location, distribution and spatial arrangement of the hunting blinds recorded in this region suggests that they were regularly employed as tactical options in ambush hunting strategies, particularly in the Late Holocene (Belardi et al. 2013; Cassiodoro et al. 2014; Goñi et al. 2014, 2016). In addition to radiocarbon dates, the late chronology of hunting blinds is strongly supported by contextual evidence such as the presence of pottery sherds, certain rock art motifs and projectile point designs assigned to the last 2500 years BP (Belardi et al. 2013; Cassiodoro et al. 2014; Goñi et al. 2014). Ethnohistorical sources, ethnographic models and archaeological data led Goñi (2010) to suggest that after the introduction of the horse (in the eighteenth century $\mathrm{AD})$, the organisation of human activities — and especially hunting strategies — changed in a number of ways, and the blinds may have ceased to be used, at least on a regular basis.

The aim of this article is twofold. Firstly, it will present and discuss recently collected evidence about hunting blinds in two arid cold steppe landscapes that represent the geographic extremes of a major Late Holocene cultural and social interaction area in southern Patagonia (Belardi \& Goñi 2006; Goñi et al. 2014): a) the western basaltic plateaux (Cardiel Chico and El Tobiano, $900-1100 \mathrm{~m}$ asl); and b) the central Deseado Massif, extra-Andean Patagonia (hills and sedimentary/basaltic plateaux $\leq 1000 \mathrm{~m}$ asl) (Figure 1). Secondly, it will model different hunting tactics that functioned within a general close-encounter, ambush hunting strategy based on the use of blinds in order to contribute 


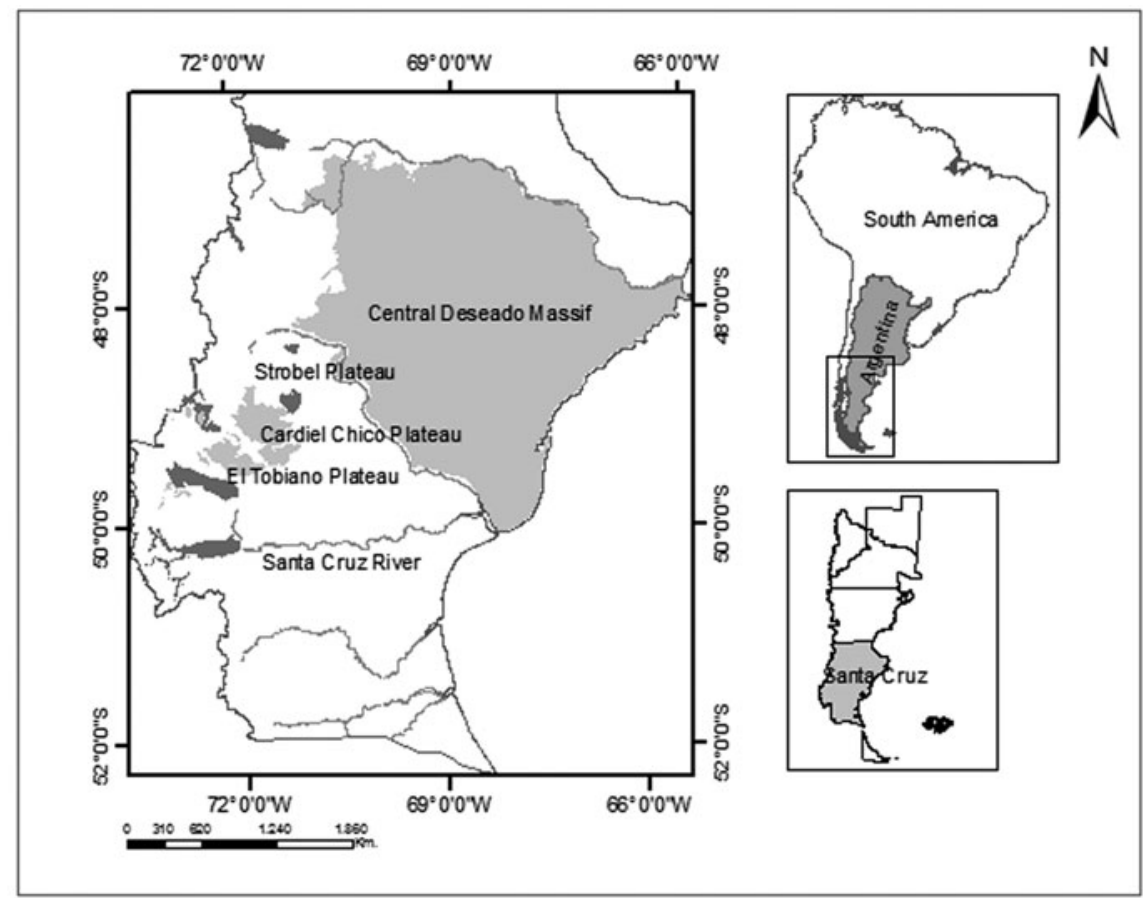

Figure 1. Location of the landscapes and places surveyed.

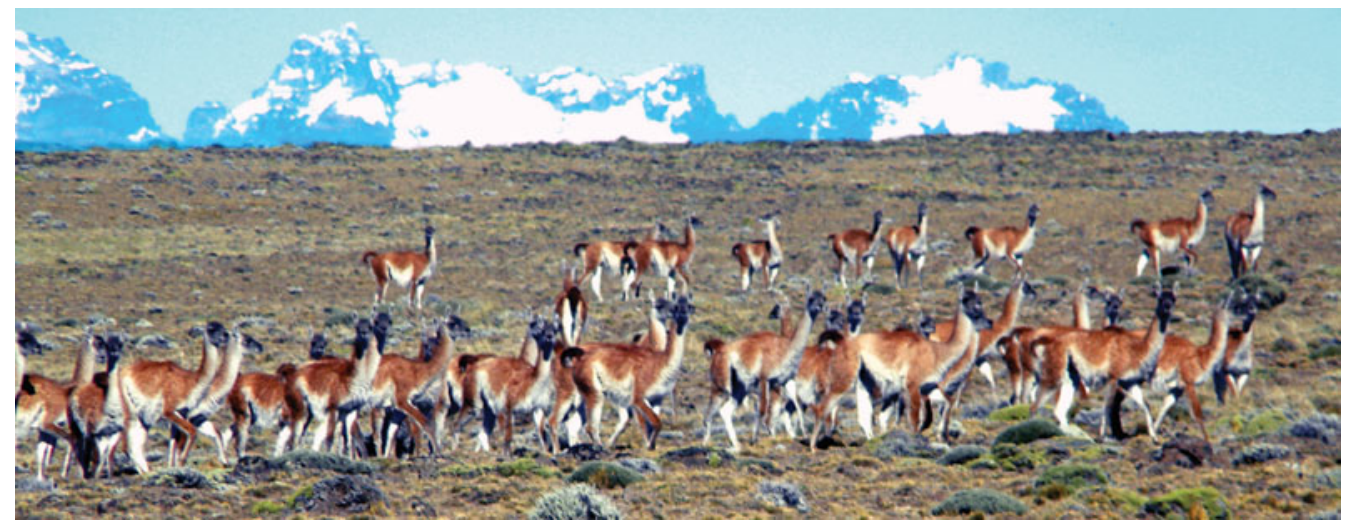

Figure 2. Guanaco family group on the Tobiano basaltic plateau. The Andes range is seen on the horizon.

to the wider discussion about the tactical deployment of special facilities for the hunting of ungulates (e.g. Bar-Oz \& Nadel 2013).

\section{Guanacos: population structure and behaviour}

The guanaco is a generalist, medium-sized herbivore $(90-120 \mathrm{~kg})$, characterised by a social organisation based on a polygynous mating system (González et al. 2006). Even though it is mostly a grazer, it can also browse according to food availability and season (Figure 2).

(C) Antiquity Publications Ltd, 2017 
Its behaviour may be described as seasonally territorial, with some exceptions mainly related to zones with year-round water availability. Three basic social groups are found in wild populations: family groups, male groups and solitary individuals (González et al. 2006). Holocene hunter-gatherers took advantage of the relatively predictable family group distribution of guanacos resulting from the territorial behaviour of males (Kaufmann 2009).

Current guanaco population density in southern Patagonia is high (1.1-7.4 individuals $/ \mathrm{km}^{2}$ ) and very variable across space. Western basaltic plateaux are the preferred calving areas (late spring and summer); the availability of guanacos in this environment is therefore seasonal and its high density is due to the presence of different social groups. By contrast, in the central Deseado Massif, guanacos are available year round, but their density is lower owing to their more widely spread distribution (Travaini et al. 2015 and references therein). Although estimating past guanaco distribution and density are difficult, they are expected to have been similar to present-day values, at least in relative-mainly spatial-terms.

\section{Previous knowledge about hunting blinds in southern Patagonia}

Hunting tactics during most of the human occupation of southern Patagonia did not involve the use of hunting blinds. Rock paintings - attributable to the Early Holoceneshow scenes of collective hunting, with hunters guiding guanaco herds towards rugged landforms where they were intercepted by other hunters. Those images also show the use of stone bolas (Aschero 2012). The appearance and intensive use of tended structures for hunting during the Late Holocene show a new relationship between human pedestrian populations and their main prey, probably related to changes in both guanaco behaviour and human population density.

Hunting blinds were constructed using rocks available locally (mostly basalt), facing the prevailing western winds so as to offer shelter to hunters who tried to avoid being scented by the prey. On occasions, hunters seem to have used elements of local topography such as natural steps in basalt formations or rocky outcrops to conceal themselves, sometimes also using boulders placed purposefully on an outcrop to gain height for their shelter. The artefacts commonly found inside the blinds consist of bases and fragments of projectile points, as well as tiny microflakes, suggesting point replacement and the final retouching of edges (e.g. Hermo 2008; Magnin 2010; Goñi et al. 2014). It is notable that some hunting blinds are currently being reused by contemporary chulengo (i.e. young guanaco) hunters.

Most southern Patagonian hunting blinds are located on the top of basaltic plateaux or on access roads leading to them: Buenos Aires Lake Plateau (Gradin 1996), Guitarra Lake Plateau (Goñi et al. 2010), Pampa del Asador (Espinosa \& Goñi 1999), Perito Moreno National Park and the foothills of the Águila Plateau (Molinari \& Ferraro 2004; Cassiodoro et al. 2014), Strobel Plateau (Flores Coni 2014; Goñi et al. 2014) and Cardiel Chico Plateau (Belardi et al. 2013 and this article). These plateaux are covered with snow throughout autumn and winter due to their high altitude; their use by hunter-gatherer populations would therefore have occurred in late spring and summer. In addition, the 
plateaux are surrounded by low-altitude lake basins $(250-275 \mathrm{~m}$ asl) that were used by hunter-gatherers year-round. In the central Deseado Massif, hunting blinds are located on hills, small plateaux and rocky outcrops, taking advantage of the uneven terrain (Hermo 2008; Magnin 2010).

No radiocarbon dates were obtained from the hunting blinds, either in the Cardiel Chico/El Tobiano basaltic plateaux or in the central Deseado Massif sample, due to the lack of organic archaeological material. As mentioned above, however, radiocarbon data from nearby plateaux and the central Deseado Massif indicate that the occupation of this environment occurred mainly over the last 2500 years BP.

\section{Present study}

\section{The landscapes}

The climate of the western basaltic plateaux (Ramos 2002) and the central Deseado Massif (Panza 2001) (Figure 1) is arid cold steppe, with mean temperatures between 8 and $10^{\circ} \mathrm{C}$. In both landscapes the vegetation has a patchy distribution and is composed of shrubs, sub-shrubs and gramineous species, whose occurrence is associated with natural drainage systems (Oliva et al. 2001).

Western basaltic plateaux have relatively homogeneous, flattened surfaces with plenty of ponds, characterised not only by the presence of hunting blinds but also by the availability of water and shelter, provided by the basaltic walls that surround the ponds. Good-quality igneous and sedimentary rocks are available for knapping (Espinosa et al. 2015), a resource that was complemented by the transfer of allochthonous obsidians from Pampa del Asador (Espinosa \& Goñi 1999). These characteristics, along with the seasonal availability of guanacos, make these basaltic plateaux an important attractor for human activity.

The central Deseado Massif has a slightly uneven surface morphology characterised by vast sedimentary plains with a slight eastward slope. The landscape is jagged, with hills and isolated volcanic cones, alternating with rocky outcrops and small plateaux crossed by longitudinal and transverse valleys. In striking contrast to the western basaltic plateaux, there are numerous rockshelters and caves. The fluvial system is composed of seasonal bodies of water (De Giusto et al. 1980). There is a high availability of good-quality, but heterogeneously distributed, lithic raw materials for knapping (Cattáneo 2002; Hermo 2008; Franco et al. 2015, among others). As in the western basaltic plateaux, the widespread use of black obsidian from Pampa del Asador is also recorded (Molinari \& Espinosa 1999; Franco et al. 2015).

Both landscapes share the same complex of engraved geometric and figurative motifs, which appear to be associated with living and hunting areas (Goñi et al. 2007, 2014; Carden 2008; Acevedo et al. 2012-2014; Blanco 2014). Although there are noticeable spatial differences in the richness of motifs as well as in the density of representations (higher in the plateaux and western Deseado Massif, fewer in the eastern Deseado Massif), a common major interaction area could be proposed on this basis and other contextual evidence (e.g. (C) Antiquity Publications Ltd, 2017 
exploitation of the same obsidian sources, generation of similar hunting landscapes) (Belardi \& Goñi 2006; Goñi et al. 2014).

\section{Methodology}

Hunting blinds were surveyed during several field seasons by means of a semi-random search around areas in which their presence was suspected. A variable number of observers (between two and five) participated in each field season. Data collection took into account the following variables: a) geographic coordinates (measured in degrees, minutes and seconds with GPS); b) geomorphological setting; c) degree of clustering (determined by the presence of two or more structures within a $20 \mathrm{~m}$ radius around the first detected structure); d) shape (semi-elliptical/linear); e) size (chord line, sagitta and wall height measured in centimetres); and f) absence/presence of artefacts inside or around each blind.

In addition, in the case of the western basaltic plateaux, we also used a slide calliper to record the stem width of the projectile points recovered inside the blinds and in their immediate surroundings (four associated projectile points were recorded in the central Deseado Massif, but no metric information is available). The aim was to distinguish the probable use of different weapon systems, namely throwing spear and bow and arrow. Stem widths less than $10 \mathrm{~mm}$ were considered to belong to arrowheads, while stem widths greater than $10 \mathrm{~mm}$ were assumed to correspond to points of throwing spears (Churchill 1993; Ratto 2012). The high rate of blade fracture and loss precluded any further metric analysis on the recovered points and point fragments.

\section{Distributional and dimensional data results}

The presence of hunting blinds at Cardiel Chico and Tobiano plateaux (in the western basaltic plateaux) (Table $1 \&$ Figure $3 \mathrm{a}-\mathrm{c}$ ) is more frequent than in the central Deseado Massif (Table $2 \&$ Figure 3e-g). Moreover, these landscapes differ in the density of hunting blinds per $\mathrm{km}^{2}: 2.8$ in the western basaltic plateaux and 0.3 in the central Deseado Massif. Likewise, in the former landscape, clusters of hunting blinds prevail over isolated ones, with marked variations in frequency. In contrast, in the central Deseado Massif, most hunting blinds are isolated ( 52.5 per cent) and the clusters are composed of a smaller number of structures (between two and five). Despite these differences between the two landscapes, they share a high frequency of semi-elliptical hunting blinds and the same distribution of size intervals (Figure 4).

The stem width of projectile points recovered from blinds in the western basaltic plateaux (mostly obsidian) indicates the prevalence of throwing spears (Figure 5). These weapons are frequently used when the prey is at a disadvantage, mostly in the context of communal hunting (Churchill 1993). In the Cardiel Chico plateau, however, the use of bow and arrow can also be inferred. This weapon can be very efficient for hunting camelids, as the method is rapid, noiseless and does not provoke stampedes (Yacobaccio \& Vilá 2013). In two structures, both spear and arrow points were found, although it is at present difficult to say with confidence that both weapon systems were conjointly used in the same hunting events. 
Table 1. Hunting blinds from the western basaltic plateaux (Figure 1). Surveyed area: $49 \mathrm{~km}^{2}$.

\begin{tabular}{llll}
\hline Clustered/isolated & $\begin{array}{l}\text { Number } \\
\text { of blinds }\end{array}$ & $\begin{array}{c}\text { Semi- } \\
\text { elliptical }\end{array}$ & Linear \\
\hline
\end{tabular}

\section{Cardiel Chico Plateau (hunting blinds $\mathbf{n}=108$ )}

\begin{tabular}{lccc} 
Cluster 1 & 4 & 3 & 1 \\
Cluster 2 & 8 & 7 & 1 \\
Cluster 3 & 11 & 11 & - \\
Cluster 4 & 6 & 6 & - \\
Cluster 5 & 9 & 9 & - \\
Cluster 6 & 3 & 2 & 1 \\
Cluster 7 & 3 & 3 & - \\
Cluster 8 & 2 & 2 & - \\
Cluster 9 & 6 & 6 & - \\
Cluster 10 & 8 & 4 & 4 \\
Cluster 11 & 4 & 4 & - \\
Cluster 12 & 3 & 3 & - \\
Cluster 13 & 4 & 3 & 1 \\
Cluster 14 & 11 & 5 & 6 \\
Isolated & 26 & 20 & 6 \\
El Tobiano Plateau (hunting blinds n $=30)$ & & \\
Cluster 1 & 2 & 1 & 1 \\
Cluster 2 & 13 & 10 & 3 \\
Cluster 3 & 2 & 1 & 1 \\
Cluster 4 & 8 & 8 & - \\
Cluster 5 & 2 & 2 & - \\
Isolated & 3 & 2 & 1 \\
\hline
\end{tabular}

Table 2. Hunting blinds from the central Deseado Massif (Figure 1). Surveyed area: $129 \mathrm{~km}^{2}$. Hunting blinds $\mathrm{n}=40$.

\begin{tabular}{llccc}
\hline Surveyed places & $\begin{array}{l}\text { Clustered/ } \\
\text { isolated }\end{array}$ & $\begin{array}{c}\text { Number } \\
\text { of blinds }\end{array}$ & $\begin{array}{c}\text { Semi- } \\
\text { elliptical }\end{array}$ & $\begin{array}{c}\text { Linear } \\
\text { Ea. La Patricia }\end{array}$ \\
Ea. Las Bayas & Isolated & 1 & 1 & - \\
Ea. Leonardo & - & 2 & 2 & - \\
Ea. El Cóndor & - & 2 & 2 & - \\
Ea. El Cóndor. Michelle Sur & Cluster 1 & 2 & 2 & - \\
Ea. La Magdalena & Cluster 1 & 2 & 2 & - \\
Ea. La Josefina & Isolated & 1 & 1 & - \\
& Cluster 1 & 5 & 5 & - \\
Ea. La Marcelina & Cluster 2 & 4 & 4 & - \\
& Isolated & 11 & 8 & 3 \\
Ruta 39 & Cluster 1 & 4 & 3 & 1 \\
& Cluster 2 & 2 & 2 & - \\
& Isolated & 1 & - & 1 \\
& Isolated & 2 & 2 & - \\
\hline
\end{tabular}

(C) Antiquity Publications Ltd, 2017 

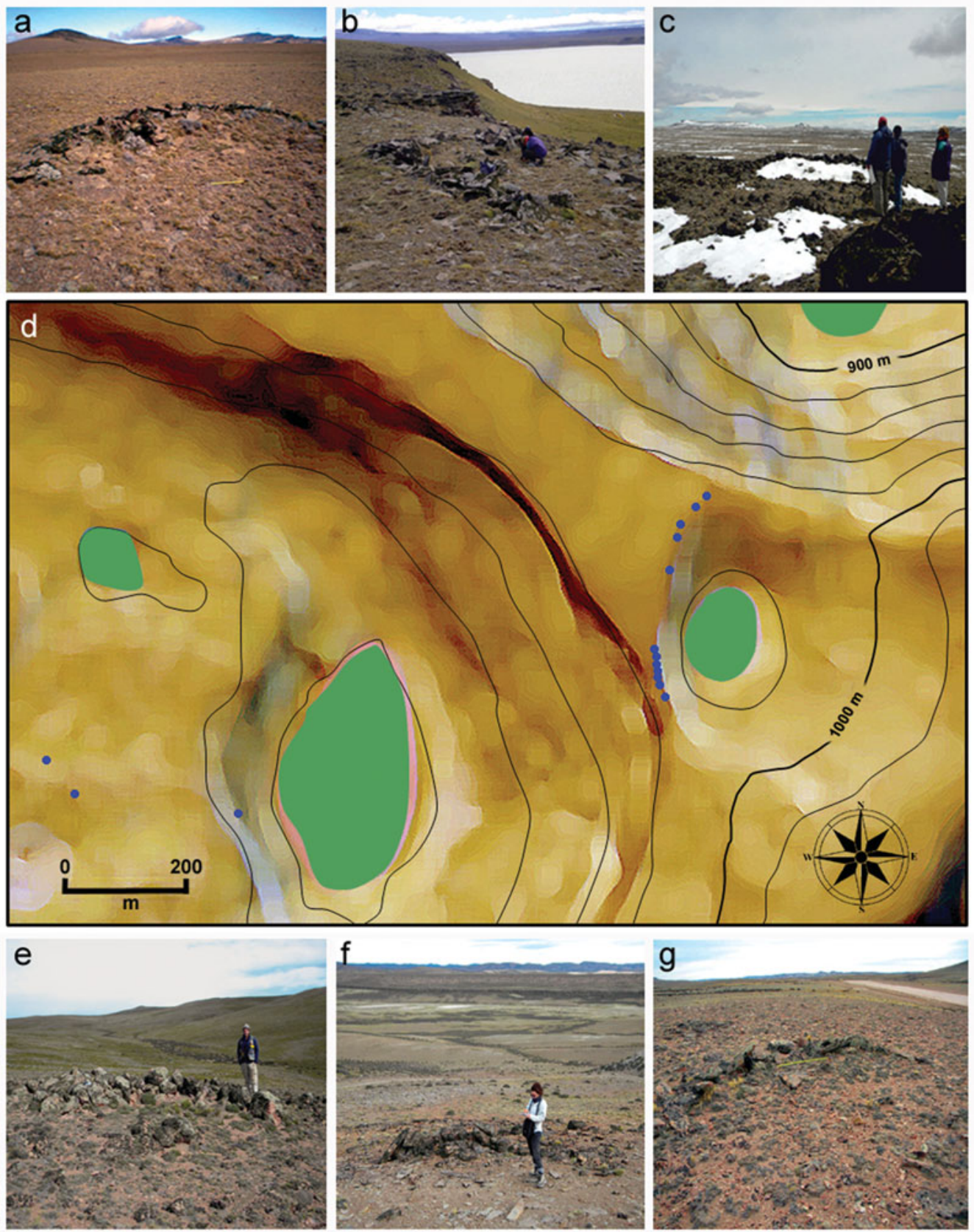

Figure 3. a-c) Hunting blinds from Cardiel Chico basaltic plateau; d) distribution of blinds (blue dots) at El Tobiano plateau; e-g) hunting blinds from the central Deseado Massif. 


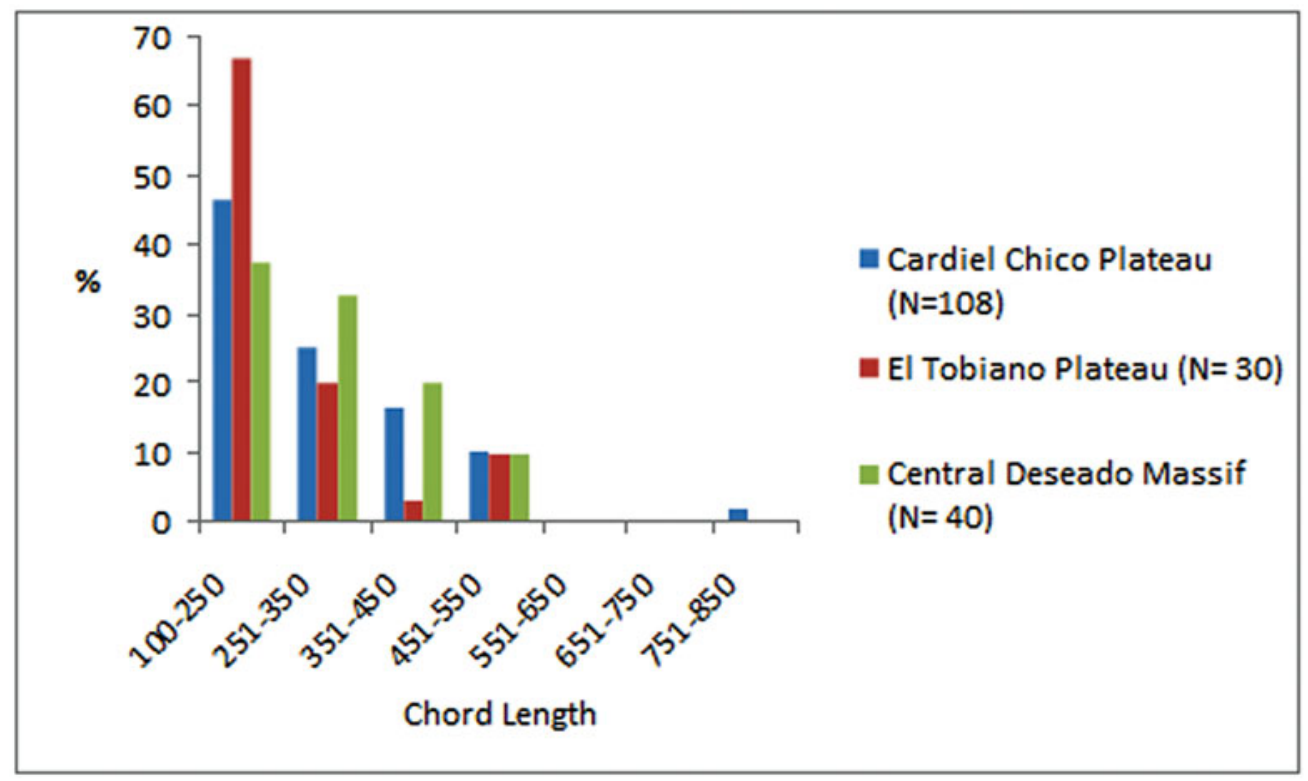

Figure 4. Histograms of relative frequency (\%) of hunting blind chord length (in cm).

\section{Modelled guanaco hunting tactics involving blinds}

Guanaco hunting tactics using hunting blinds were modelled based on location, distribution and spatial arrangement of the structures (Figure 6). The tactics inferred included both individual and communal hunting, i.e. the action of individuals working together for a common purpose or goal (see Hockett et al. 2013). Individual hunting occurs when a hunter employs a small-sized, isolated, usually linear, hunting blind (tactic one). Communal hunting involves the use of a cluster of hunting blinds in the plains (tactic two), with hunters waiting for the different guanaco social groups to go into or out of the ponds (tactics three and four), on the downward slopes of the plateaux (tactic five), on the plains between ponds (tactic six); and by using natural narrows in order to direct guanacos to linear arrangements of hunting blinds (tactic seven; see also Figure 3d). Tactics one to four are common to both of the landscapes described here.

These tactics reveal that communal hunting using structures seems to have been more important in the western basaltic plateaux, from the greater frequency of clustered hunting blinds in that region. Coordinated activities between hunters could have also required the presence of individuals flushing out the prey near the hunting blinds. The predominance in both landscapes of blinds with chord lengths in the $1-2.5 \mathrm{~m}$ and $2.51-$ $3.5 \mathrm{~m}$ categories (Figure 4) may indicate that these blinds were designed to accommodate a small number of hunters. The only case that does not follow this trend is a large hunting blind on the Cardiel Chico plateau, which might have been used by a larger group of hunters.

(C) Antiquity Publications Ltd, 2017 


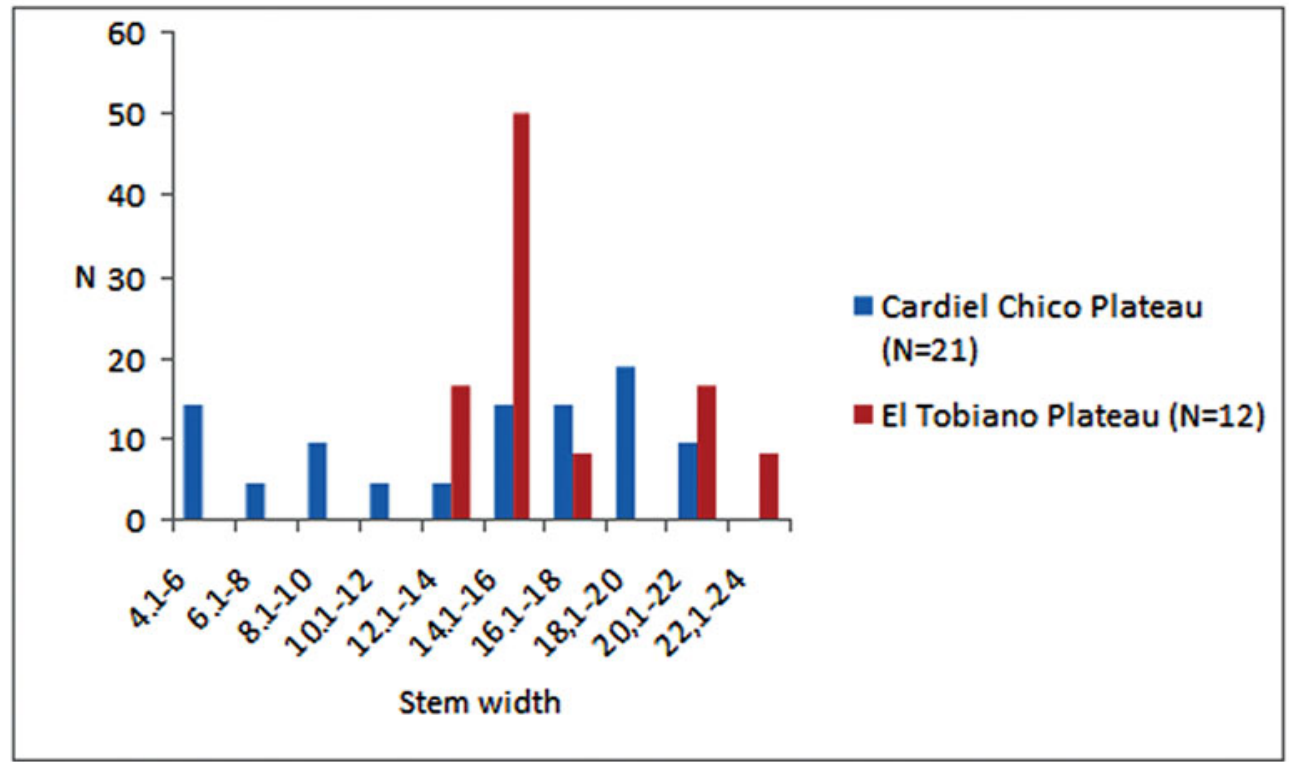

Figure 5. Histograms of absolute frequency of projectile point stem width (in $\mathrm{mm}$ ).

1)

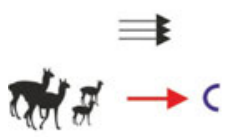

4) $\Longrightarrow$

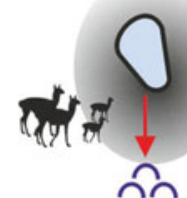

2)<smiles>C#CC(C)(C)O</smiles>

3)

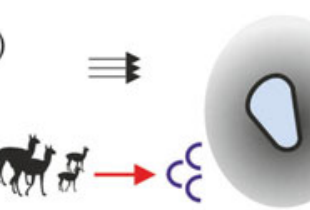

5)<smiles>C#C</smiles>

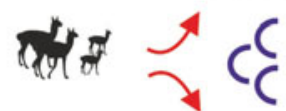

Plateau access - exit

6)

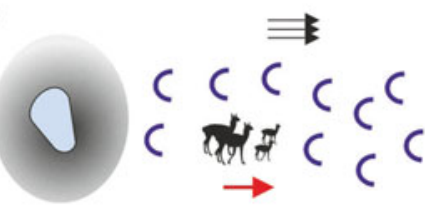
c

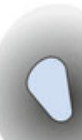

Figure 6. Modelled hunting tactics (see references in text).

(C) Antiquity Publications Ltd, 2017 


\section{Discussion and conclusions}

Overall, the western basaltic plateaux and the central Deseado Massif landscapes seem to have had both similarities and differences as hunting grounds during the Late Holocene. The similarities in the shapes of hunting blinds, their sizes and specific hunting tactics between both landscapes can be explained either by functional constraints (guanaco population structure and behaviour), common traditions (shared cultural/social practices and ideas) or both. As mentioned above, there is strong contextual evidence supporting the hypothesis of a broad social interaction sphere, and hence of a shared cultural transmission system operating in southern Patagonia north of the Santa Cruz River, particularly centred around the Strobel plateau ('convergence model'; Belardi \& Goñi 2006; Goñi et al. 2007, 2014).

Differences in the frequency and diversity of blinds, as well as in the inferred hunting tactics, can be explained by differences in topography, seasonality, prey biomass and huntergatherer density. The higher frequency and density of hunting blinds, and the variety of tactics identified at the Cardiel Chico and Tobiano plateaux, are in general agreement with data from other western basaltic plateaux (Cassiodoro et al. 2014; Goñi et al. 2014, among others). They are also in accord with the model described above, which proposes the use of these high-altitude environments either as seasonally exploited hunting grounds, approached logistically from lower lake basins (Cardiel, San Martin and Viedma), or as places of more stable occupation by hunter-gatherer family groups. The information presented in this study can help to establish meaningful distinctions in terms of human land-use patterns, particularly calling attention to the relative importance of highland settings as major and reliable sources of critical resources for foraging peoples, a topic that is still not fully appreciated in archaeological studies of hunter-gatherers (Binford 2009: 220).

Finally, the information presented in this article, particularly the combined use of hunting blinds and bows and arrows recorded at the Cardiel Chico plateau, suggests a scenario of increasing hunting pressure on guanacos in Late Holocene times (L'Heureux 2008). This could have been related to a general human population increase in southern Patagonia (Borrero 1994-1995; Goñi 2010; Belardi et al. 2013), or to a differential distribution of population across this region (Borrero 1994-1995; Goñi et al. 20002002; Belardi \& Goñi 2006). This widespread 'hunting blind landscape' is not present south of the Santa Cruz River (Figure 1), probably owing to differences in regional topography as well as to a lower human population density (Borrero 1994-1995). In any case, a more detailed comparison with areas inside and outside Patagonia is needed in order to shed more light on this problem and on the broader issue of the relationship between hunting technology, population density and intensification (Tomka 2013; Morgan 2015).

\section{Acknowledgements}

We thank the Jordana family and H. Hernández, from Ea. San Adolfo, and Ana Rojo, from Ea. Punta del Lago, for their hospitality and field assistance. María Clara Álvarez, Luis Borrero, Gustavo Martínez, Peter White and two anonymous reviewers contributed valuable comments. The research was conducted with grants provided (C) Antiquity Publications Ltd, 2017 
by the Universidad Nacional de la Patagonia Austral, Unidad Académica Río Gallegos, Proyecto 29/A304-1 and CONICET PIP-11220120100622CO (Res. 4316).

\section{References}

Acevedo, A., D. Fiore, N. Franco \& M. Ocampo. 2012-2014. Arte y espacio. Estructuración de los repertorios de arte rupestre en los cañadones Yaten Guajen y El Lechuza (margen norte del río Santa Cruz, Patagonia, Argentina). Mundo de Antes 8: 9-33.

Aschero, C. 2012. Las escenas de caza en Cueva de las Manos: una perspectiva regional (Santa Cruz, Argentina), in J. Clottes (ed.) L'art pléistocene dans le monde/Pleistocene art of the World/Arte pleistoceno en el mundo, Actes du Congres IFRAO, Tarascon-sur-Ariège, septembre 2010 (Numéro spécial de Préhistoire, Art et Sociétes, Bulletin de la Societé Préhistorique Ariège-Pyrénées 65-66): 140-41. Tarascon-sur-Ariège: Societé Préhistorique Ariège-Pyrénées.

Aschero, C. \& J. Martínez. 2001. Técnicas de caza en Antofagasta de la Sierra, Puna Meridional argentina. Relaciones de la Sociedad Argentina de Antropología NS 26: 2015-41.

BAR-Oz, G. \& D. NADEL. 2013. Worldwide large-scale trapping and hunting of ungulates in past societies. Quaternary International 297: 1-7. https://doi.org/10.1016/j.quaint.2013.01.029

Belardi, J.B. \& R.A. GoÑi. 2006. Representaciones rupestres y convergencia poblacional durante momentos tardíos en Santa Cruz (Patagonia argentina). El caso de la meseta del Strobel, in D. Fiore \& M.M. Podestá (ed.) Tramas en la piedra. Producción y usos del arte rupestre: 85-94. Buenos Aires: World Archaeological Congress, Sociedad Argentina de Antropología y Asociación Amigos del Instituto Nacional de Antropología.

Belardi, J.B., S. Espinosa, G. Barrientos, F. Carballo Marina, A. Re, P. Campan, A. Súnico \& F. Guichon. 2013. Las mesetas de San Adolfo y Cardiel Chico: estrategias de movilidad y tácticas de caza de guanacos en el SO de Santa Cruz, in F. Zangrando, R. Barberena, A. Gil, G. Neme, M. Giardina, L. Luna, C. Otaola, L. Paulides, L. Salgan \& A. Tívoli (ed.) Tendencias teórico-metodológicas y casos de estudio en la arqueología de Patagonia: 261-70. Buenos Aires: Altuna.

BINFord, L.R. 1978a. Nunamiut ethnoarchaeology. New York: Academic.

- 1978b. Dimensional analysis of behaviour and site structure: learning from an Eskimo hunting stand. American Antiquity 43: 330-61. https://doi.org/10.2307/279390
- 2001. Constructing frames of reference: an analytical method for archaeological theory building using ethnographic and environmental data sets. Berkeley \& Los Angeles: University of California Press.

- 2009. Nunamiut subsistence provinces - the mountain area: hunting with bow and bow versus gun, in B. Grønnow (ed.) On the track of the Thule Culture from Bering Strait to East Greenland. Proceedings of the SILA Conference 'The Thule Culture-New Perspectives in Inuit Prehistory' Copenhagen, October $26^{\text {th }}-28^{\text {th }}$, 2006. Papers in honour of Hans Christian Gulløv: volume 15: 211-22. Copenhagen: National Museum.

Blanco, R. 2014. El arte rupestre en los Macizos del Deseado y Somuncurá: la producción de grabados y pinturas entre cazadores recolectores desde el Holoceno medio. Unpublished PhD dissertation, Universidad Nacional de La Plata.

Borrero, L.A. 1994-1995. Arqueología de la Patagonia. Palimpsesto. Revista de Arqueología 4: 9-70.

- 2001. El poblamiento de la Patagonia. Toldos, milodones y volcanes. Buenos Aires: Emecé.

- 2013. Estrategias de caza en Fuego-Patagonia. Comechingonia 17(1): 11-22.

Carden, N. 2008. Imágenes a través del tiempo. Arte rupestre y construcción social del paisaje en la Meseta Central de Santa Cruz. Buenos Aires: Sociedad Argentina de Antropología.

Cassiodoro, G., A. Re \& D. Rindel. 2014. Estrategias de caza en espacios alto de Patagonia Meridional durante el Holoceno tardío: evidencia arqueofaunística, tecnológica y rupestre, in G. Cassiodoro, A. Re \& D. Rindel (ed.) Integración de diferentes líneas de evidencia en la arqueología argentina: 113-37. Buenos Aires: Aspha.

Cattáneo, G.R. 2002. Una aproximación a la organización de la tecnología lítica entre cazadores-recolectores del Holoceno Medio/Pleistoceno Final de la Patagonia Austral (Argentina). Unpublished PhD dissertation, Universidad Nacional de La Plata.

Churchill, S. 1993. Weapon technology, prey size selection, and hunting methods in modern hunter-gatherers: implications for hunting in the Paleolithic and Mesolithic, in G.L. Peterkin, H. Bricker \& P.A. Mellars (ed.) Hunting and animal exploitation in the later Paleolithic and Mesolithic of Eurasia: 11-24. Washington, D.C.: American Anthropological Association.

De Giusto, J.M., C.A. Di Persia \& E. Pezzi. 1980. Nesocratón del Deseado. Segundo Simposio de Geología Regional Argentina. Volume II: 1389-430.

(C) Antiquity Publications Ltd, 2017 
Espinosa, S.L. \& R. GoÑI. 1999. ¡Viven!: una fuente de obsidiana en la provincia de Santa Cruz, in Instituto Nacional de Antropología y Pensamiento Latinoamericano and Universidad Nacional del Comahue (ed.) Soplando en el viento ... Actas de las Terceras Jornadas de Arqueología de la Patagonia: 177-88. Buenos Aires: Presidencia de la Nacioń, Secretaria de Cultura, Instituto Nacional de Antropologiá y Pensamiento Latinoamericano.

Espinosa, S.L., J.B. Belardi, G. Barrientos, P. Campan \& A. Súnico. 2015. Disponibilidad, circulación y uso de materias primas líticas en las cuencas de los lagos Tar y San Martín (provincia de Santa Cruz, Argentina). Intersecciones en Antropología 2 (special issue): 101-11.

Flores Coni, J. 2014. Análisis de la variabilidad de los parapetos en la meseta del Strobel (Santa Cruz). Relaciones de la Sociedad Argentina de Antropología NS 39 (1-2): 551-57.

Franco, N.V., N.A. Cirigliano, L. Vitrisano \& P. Ambrústolo. 2015. Raw material circulation at broad scales in southern Patagonia (Argentina): the cases of the Chico and Santa Cruz River basins. Quaternary International 375: 72-83. https://doi.org/10.1016/j.quaint.2014.11.058

Frison, G. 2004. Survival by hunting: prehistoric human predators and animal prey. Berkeley: University of California Press. https://doi.org/10.1525/california/ 9780520231900.001.0001

GoÑı, R.A. 2010. Cambio climático y poblamiento humano durante el Holoceno tardío en Patagonia Meridional. Una perspectiva arqueológica. Unpublished PhD dissertation, Universidad de Buenos Aires.

Goñi, R.A., G. Barrientos \& G. Cassiodoro. 2000-2002. Las condiciones previas a la extinción de las poblaciones humanas del sur de Patagonia: una discusión a partir del análisis de la estructura del registro arqueológico de la cuenca del Lago Salitroso. Cuadernos del Instituto Nacional de Antropología y Pensamiento Latinoamericano 19: 249-66.

Goñi, R.A, J.B. Belardi, A. Re, A. Nuevo Delaunay, R. Molinari \& L. Ferraro. 2007. Los grabados de la meseta del lago Strobel (Patagonia Argentina) desde una perspectiva regional, in R. Hostig, M. Strecker \& J. Guffroy (ed.) Actas del Primer Simposio Nacional de Arte Rupestre (Cusco, noviembre de 2004). Actes \& Memoires de l'Institut français d'Études andines: Tomo 12: 427-38. Lima: Instituto Francés de Estudios Andinos, Institut pour le devéloppement, Embajada de la República Federal de Alemania.
Goñi, R.A., G. Cassiodoro, A. Re, F. Guichon, J. Flores Coni \& J.M. Dellepiane. 2010. Arqueología de la meseta del lago Guitarra (Santa Cruz). Arqueología argentina en el bicentenario de la Revolución de Mayo, in R. Bárcena \& H. Chiavazza (ed.) XVII Congreso Nacional de Arqueología Argentina V: 1923-28. Mendoza: Facultad de Filosofía y Letras (UNCuyo), Instituto de Ciencias Humanas, Sociales y Ambientales (CONICET).

Goñi, R.A., A. Re, J.B. Belardi, J. Flores Coni \& F. Guichon. 2014. Un lugar muy particular. Caza, convergencia de poblaciones y circulación de información en la meseta del Strobel, in R.A. Goñi, J.B. Belardi, G. Cassiodoro \& A. Re (ed.) Arqueología de las cuencas de los lagos Cardiel y Strobel: poblamiento humano y paleoambientes en Patagonia: 155-85. Buenos Aires: Aspha.

Goñi, R.A., G. Cassiodoro, J. Flores Coni, J.M. Dellepiane, A. Agnolín \& R. Guichon. 2016. Estrategias de caza y movilidad: parapetos del sitio K116 (meseta del Strobel, Santa Cruz), in F. Mena (ed.) Arqueología de la Patagonia: de mar a mar: 441-49. Santiago: Ediciones CIEP, Nire Negro Ediciones, Andros Impresores.

González, B.A., R.E. Palma, B. Zapata $\&$ J.C. Marín. 2006. Taxonomic and biogeographical status of guanaco Lama guanicoe (Artiodactyla, Camelidae). Mammal Review 36: 157-78. https://doi.org/10.1111/j.13652907.2006.00084.x

Gradin, C. 1959-1960. Petroglifos de la meseta del lago Strobel (Provincia de Santa Cruz, Argentina). Acta Praehistorica 3-4: 144-49.

- 1996. Grabados y parapetos de la zona sur de la Meseta del Lago Buenos Aires (Prov. de Santa Cruz), in J. Gómez Otero (ed.) Arqueología. Solo Patagonia. Ponencias de las II Jornadas de Arqueología de la Patagonia: 173-84. Puerto Madryn: Publicación del Centro Nacional Patagónico (CONICET).

Hermo, D. 2008. Los cambios en la circulación de las materias primas líticas en ambientes mesetarios de la Patagonia. Una aproximación para la construcción de los paisajes arqueológicos de las sociedades cazadoras-recolectoras. Unpublished $\mathrm{PhD}$ dissertation, Universidad Nacional de La Plata.

Hockett, B., C. Creger, B. Smith, C. Young, J. Carter, E. Dillingham, R. Crews \& P. Pellegrini. 2013. Large-scale trapping features from the Great Basin, USA: the significance of leadership and communal gatherings in ancient foraging societies. Quaternary International 297 64-78.

https://doi.org/10.1016/j.quaint.2012.12.027 


\section{Late Holocene guanaco hunting grounds in southern Patagonia}

Kaufmann, C. 2009. Estructura de edad y sexo en guanacos. Estudios actualisticos y arqueológicos en Pampa y Patagonia. Buenos Aires: Sociedad Argentina de Antropología.

Laland, K.N. \& M.J. O’Brien. 2010. Niche construction theory and archaeology. Journal of Archaeological Method and Theory 17: 303-22. https://doi.org/10.1007/s10816-010-9096-6

L'Heureux, G.L. 2008. El estudio arqueológico del proceso coevolutivo entre las poblaciones humanas y las poblaciones de guanaco en Patagonia Meridional y norte de Tierra del Fuego (British Archaeological Reports international series 1751). Oxford: Archaeopress.

Magnin, L.A. 2010. Distribuciones arqueológicas en la Meseta Central de Santa Cruz. Implicancias para los estudios de uso del espacio y movilidad de sociedades cazadoras recolectoras. Unpublished $\mathrm{PhD}$ dissertation, Universidad Nacional de La Plata.

Mengoni Goñalons, G.L. 1999. Cazadores de guanaco de la Estepa Patagónica. Buenos Aires: Sociedad Argentina de Antropología.

Miotтi, L. 1998. Zooarqueología de la Meseta Centraly costa de Santa Cruz. Un enfoque de las estrategias adaptativas aborígenes y los paleoambientes. San Rafael: Museo Municipal de Historia Natural, Secretaría de Gobierno, Departamento de San Rafael, Provincia de Mendoza.

Molinari, R. \& S. Espinosa. 1999. Brilla tú, diamante 'loco', in Instituto Nacional de Antropología y Pensamiento Latinoamericano and Universidad Nacional del Comahue (ed.) Soplando en el viento ... Actas de las Terceras Jornadas de Arqueología de la Patagonia: 189-98. Buenos Aires: Presidencia de la Nacioń, Secretaria de Cultura, Instituto Nacional de Antropologiá y Pensamiento Latinoamericano.

Molinari, R. \& L. Ferraro. 2004. Estancia Menelik: implicancias para el manejo de recursos culturales en la zona de amortiguación del Parque Nacional Perito Moreno, in M.T. Civalero, P. Fernández \& A.G. Guaraieb (ed.) Contra viento y marea. Arqueología de Patagonia: 625-34. Buenos Aires: Instituto Nacional de Antropología y Pensamiento Latinoamericano \& Sociedad Argentina de Antropología.
Moreno, E. 2012. The construction of hunting sceneries: interactions between humans, animals and landscape in Antofalla Valley, Catamarca, Argentina. Journal of Anthropological Archaeology 31: 104-17. http://dx.doi.org/10.1016/jaa.2011.10.006

Morgan, C. 2015. Is it intensification yet? Current archaeological perspectives on the evolution of hunter-gatherer economies. Journal of Archaeological Research 23: 163-213. http://dx.doi.org/10.1007/s10814-014-9079-3

Oliva, G., L. González, P. Rial \& E. Livraghi. 2001. El ambiente en la Patagonia Austral, in P. Borrelli \& G. Oliva (ed.) Ganadería ovina sustentable en la Patagonia Austral. Tecnología de manejo extensivo: 19-82. Río Gallegos: Ediciones Instituto Nacional de Tecnología Agropecuaria.

PAnZA, J.L. 2001. Hoja Geológica 44769- IV. Monumento Natural Bosques Petrificados, Provincia de Santa Cruz (Boletín 258). Buenos Aires: Instituto de Geología y Recursos Minerales \& Servicio Geológico Minero Argentino.

Ramos, V. 2002. El magmatismo Neógeno de la cordillera patagónica. Geología y recursos naturales de Santa Cruz, in M. Haller (ed.) Relatorio del XV Congreso Geológico Argentino: 187-99. Buenos Aires: Asociacioń Geologica Argentina.

Ratto, N. 2012. Diversidad de tecnología de caza en la Puna transicional de Chaschuil (Dpto. Tinogasta, Catamarca). Comechingonia 17(1): 83-101.

Smith, B.D. 2013. Modifying landscapes and mass kills: human niche construction and communal ungulate harvests. Quaternary International 297: 8-12. http://dx.doi.org/10.1016/j.quaint.2012.12.006

Tomka, S. 2013. The adoption of the bow and arrow. A model based on experimental performance characteristics. American Antiquity 78: 553-69. https://doi.org/10.7183/0002-7316.78.3.553

Travaini, A., S.C. Zapata, J. Bustamante, J. Pedrana, J. Zanón \& A. Rodríguez. 2015. Guanaco abundance and monitoring in southern Patagonia: distance sampling reveals substantially greater numbers than previously reported. Zoological Studies 54: 23.

https://doi.org/10.1186/s40555-014-0097-0

Yacobaccio, H. \& B. Vilá. 2013. La domesticación de los camélidos andinos como proceso de interacción humana y animal. Intersecciones en Antropología 14: 227-38.

Received: 10 March 2016; Accepted: 9 June 2016; Revised: 24 June 2016 